\title{
PEMBELAJARAN BLENDED LEARNING BERBASIS SCHOOLOGY PADA MATA KULIAH PENDIDIKAN AGAMA ISLAM
}

\author{
Dewi Anggraeni*, Layla Az Zahra, Ridwan Arifin Shoheh \\ Universitas Negeri Jakarta, Indonesia \\ *E-mail:dewianggraeni@unj.ac.id
}

\begin{abstract}
Islamic Religious Education has a very significant role in bringing about national ideals. Blended learning in the PAI course is one of the efforts made in developing learning media and the PAI learning process. This model combines face-to-face and online systems. The purpose of this study is to examine how the design of blended learning models in PAI courses with reference to the PAI curriculum at PTU. The implementation of the blended learning model is using Schoologybased LMS. This research is a descriptive qualitative research that emphasizes how the learning process with the blended learning model takes place. The results of this study indicate that: 1) Blended Learning will be effective when it is designed with planning and using a variety of media that make it more innovative in learning, 2) conducting Blended Learning combination with syncronus and asyncrouns methods makes student interaction was more enthusiastic, 3) Schoologybased PAI learning as a whole received a positive response from students as a new innovation in learning $P A I$ in the digital
\end{abstract}

Keywords: Blended Learning, Sychooloy, Islamic Religious Education

Abstrak. Pendidikan Agama Islam memiliki peran yang sangat signifikan dalam mewnjdukan cita-cita nasional.. Pembelajaran blended learning pada mata kuliah Pendidikan Agama Islam (PAI) merupakan salah satu upaya yang dilakukan dalam mengembangkan media pembelajaran serta proses pembelajaran PAI. Tujuan penelitian ini adalah mengkaji bagaimana desain model pembelajaran blended learning pada mata kuliah PAI dengan mengacu kepada kurikulum PAI di PTU. Implementasi model pembelajaran blended learning adalab dengan menggunakan LMS berbasis Schoology. Penelitian ini merupakan jenis penelitian kualitatif deskrpitif yang menekanakan kepada bagaimana proses pembelajaran dengan model blended learning berlangsung. Hasil dari penelitian ini menunjukan bahwa: 1) Pembelajaran Blended Learning akan efektive ketika didesain dengan perncanaan serta menggunakan berbagai macam media yang membuat lebih inovatif dalam pembelajaran, 2) Pada pelaksanan pembelajaran kombinasi Blended Learning dengan metode syncronus dan asyncrouns membuat interkasi belajar mahasiswa lebih antusias, 3) Pembelajaran PAI berbasis schoology secara keseluruhan mendapat respon yang positif dari mahasiswa sebagai sebuah inovasi baru dalam pembelajaran PAI di era digital.

Kata Kunci: Blended Learning, Schoology, Pendidikan Agama Islam (PAI) 


\section{PENDAHULUAN}

Pendidikan Agama memiliki peran yang sangat signifikan dalam pembentukan watak dan kepribadian manusia Indonesia, dalam rangka mewujudkan pembangunan nasional yang dicita-citakan oleh bangsa ini. Atas dasar tersebut Pendidikan Agama Islam merupakan salah satu muatan wajib dalam kurikulum disetiap jenjang pendidikan sebagaimana yang tertuang dalam Sisdiknas No 20 Tahun 2003 disebutkan bahwa "Pendidikan nasional berfungsi mengembangkan kemampuan dan membentuk watak serta peradaban bangsa yang bermartabat dalam rangka mencerdaskan bangsa, bertujuan untuk mengembangkan potensi peserta didik agar menjadi manusia yang beriman dan bertakwa kepada Tuhan Yang Maha Esa, berakhlak mulia, sehat, berilmu, cakap, kreatif, mandiri, dan menjadi warga Negara yang demokratis serta bertanggung jawab" "Undang-Undang Republik Indonesia Nomor 20 Tahun 2003 Tentang Sistem Pendidikan Nasional," n.d.)

Ada dua kalimat penting yang perlu dicermati secara seksama dari bunyi Undang-Undang Sisdiknas di atas, yaitu kalimat "menjadi manusia yang beriman dan bertakwa kepada Tuhan Yang Maha Esa, berakhlak mulia," dan kalimat "menjadi warga negara yang demokratis serta bertanggung jawab." Kedua kalimat di atas sesungguhnya tidak dapat dilihat berdiri sendiri tanpa hubungan satu sama lain (Zaki, n.d.).
Kalimat-kalimat tersebut menekankan pada integritas dan sinergi tujuan Pendidikan, yaitu terbentuknya watak atau karakter dan peradaban bangsa yang bermartabat dalam rangka mencerdaskan bangsa. Kalimat pertama dalam prakteknya di semua jenjang pendidikan, terimplementasi dalam pendidikan agama, sedangkan kalimat kedua terimplementasi dalam pendidikan kewarganegaraan, pancasila atau civic education.

Namun kenyataannya, hingga saat ini posisi penting Pendidikan Agama Islam di PTU belum mewujudkan posisi penting hal ini dapat terlihat dari bagaimana antusias mahasiswa mengikuti perkuliahan berdasarkan hasil observasi awal yang dilakukan oleh peneliti dimana banyak mahasiswa yang MKU yang menggagap PAI sebagai mata kuliah suplement atau tambahan bagi mahasiswa. Di sisi lain, mahasiswa mengikuti perkuliahan PAI hanya sebatas pemenuhan SKS sebagai sarat kelulusan. Kendala lain adalah adalah bahwa metode pembelajaran PAI sebagai MKU dianggap monoton dengan metode ceramah. Sehingga hal ini berdampak kepada pembelajaran agama lebih menyenangkan untuk diikuti lewat halaqoh atau mentoring.

Dari permasalahan di atas maka untuk mencapai tujuan ideal pembelajaran PAI pada PTU perlu adanya inovasi dalam pembelajaran PAI sehingga tidak terkesan kolot dan konvensioal. Dengan harapan bahwa mahasiswa dapat mengikuti pelajaran PAI sebagai kebutuhan dan pembentukan kepribadian yang mulia. 
Salah satu upaya yang ditawarkan dalam menciptakan pembelajaran yang efektive adalah dengan penerapan model pembelajaran blended learning berbasis Schoology sebagai bentuk aktivitas proses pembelajaran yang mendorong keaktifan serta menumbuhkan kreaivitas mahasiswa serta menumbukan motivasi belajar. Pemilihan platfolm LMS schoology di didasarkan pada beberapa penelitian sebelumnya yang menunjukan bahwa pembelajaran blanded learning berbasis schoology sebagai media yang efektif digunakan untuk belajar tanpa batas (Setiyani, 2019).

Sebagaimana yang tertuang dalam SK Dirjen Dikti Nomor 43 Tahun 2006 Pasal 10 ayat (1) mengenai metodologi pembelajaran PAI sebagai mata kuliah pengembangan kepribadian yang meliputi: 1) Proses pembelajaran diselenggarakan secara interaktif, inspiratif, menyenangkan, menantang, memotivasi peserta didik untuk berpasrtisipasi aktif, serta memberian ruang yang cukup bagi prakarsa, kreativitas, dan kemandirian, dengan menempatkan mahasiswa sebagai subyek pendidikan, mitra dalam proses pembelajaran, dan sebagai umat, anggota keluarga, masyarakat dan warga negara. 2) Pembelajaran yang diselenggarakan merupaan proses mendidik, yang di dalamnya terjadi pembahasan kritis, analitis, induktif, deduktif, dan reflektif melalui dialog kreatif parsipatoris untuk mencapai pemahaman tentang kebenaran substansi dasar kajian, berkarya nyata, dan untuk menumbuhkan motivasi belajar sepanjang hayat. 3) Bentuk aktivitas proses pembelajaran: kuliah tatap muka, ceramah, dialog (diskusi) interaktif, studi kasus, penugasan mandiri, tugas baca, seminar kecil, dan kegiatan kokurikuler. 4) Motivasi: menumbuhkan kesadaran bahwa pembelajaran pengembangan kepribadian merupakan kebutuhan hidup untuk dapat eksis dalam masyarakat global.

Disinlah pentingnya dikembangkan model pembelajaran blended learning pada PAI, dimana sumbersumber belajar digital memberikan kontribusi positif dalam memberi percepatan dalam pengembangan inovasi serta metode pembelajaran, disamping itu proses pembelajaran tidak semerta-merta menghilangkan peran pendidik tetapi memaduakan antara pembelajaran yang konvensional (tatap muka) dengan pembelajaran e-learning (online).

Urgensi penelitian ini bagaimana pengembangan model pembelajaran PAI yang selama ini didominasi dengan model cermah dapat menyesuaikan dengan perkembangan zaman sebagaimana kecakapan yang dibutuhkan di era globalisasi industry dibutuhkan inovasi dalam proses pembelajaran sehingga dapat membekali peserta didik dengan berbagai kompetensi di era 21 yang berupa problem solving, komunikasi, berfikir kritis serta mampu berkolaborasi salah satunya adalah pengintegrasian pembelajaran dengan menggunakan ICT (Suana, Maharta, Nyeneng, \& Wahyuni, 2017). Salah satu kelebihan dengan model blanded dari penelitian sebelumnya adanya beberapa peningkatakan hasil belajar 
siswa(Ismarjiati et al., 2019), dalam konteks ini memberikan gambaran kepada mahasiswa bahwa pembelajaran PAI tidak selalu dengan pendekatan yang konvensional sehingga image PAI sebagai mata kuliah suplementar dapat dielakan. Selanjutnya posisi PAI sangat penting dalam konteks pendidikan mengenai agama dan kebangsaan oleh karenanya blanded leraning dapat mengarahkan mahasiswa untuk membaca litelatur keagamaan yang moderat serta sejalan dengan nilai-nilai kebangsaan. Dalam tataran ini PAI dengan belendid learning sebagai conuter ideology terhadap litelatur-litelatur keagamaan yang tersebar luas di berbagai media.

Berdasarkan hal tersebut, maka metode yang digunakan dalam penelitian ini adalah pendekatan deskriptif kualitatif dengan focus pada bagaimana desain pembelajaran PAI dengan model blended learning pada mata kuliah PAI.

Pemilihan pendekatan deskriptif berdasarkan tujuan bahwa penelitian ini mendeskripiskan proses pembelajaran dalam hal ini bagaimana desain pembelajaran dengan menggunakan model blended learning dengan menggunakan perangkat software learning management system berupa Schoology.

Penelitian ini berdasarkah hasil implementasi penerapan pemeblajaran Blanded Lerning pada mata kuliah PAI-MKU di UNJ.

Pengambilan data dilakukan lewat observasi partisipasi serta wawancara terbuka dengan mahasiwa yang mengikuti perkuliahan. Observasi partisipasi adalah observasi yang dilakukan peneliti yang ikut serta dalam kegiatan yang dilakukan oleh observant. Terdapat keuntungan yang diperoleh dari observasi partisipasif ini, yaitu observant akan bertingah laku secara wajar dan tidak dibuat-buat karena mereka tidak merasa sedang diamati karena peneliti ikut ambil bagian dalam kegiatan yang sedang berlangsung secara bersama-sama. Metode observasi yang digunakan, observasi partisipasi merupakan metode observasi terstruktur.

Wawancara merupakan teknik pengumpulan data yang dilakukan dengan seperangkat pertanyaan kepada responden untuk dijawab, wawancara yang dilakuan secara terbuka. Serta porses wawancara dilakukan secara langsung dalam perkuliahan maupun dilakuakan secara kolektif dengan menggunakan layanan coment yang terdapat pada Schoology. Pertanyan wawancara lebih menitik beratkan bagaimana penggunaan atau respon terhadap pembelajaran dengan model Blended Lerarning.

Bentuk evaluasi dilakukan berdasarkan hasil belajar siswa selama mengikuti perkuliahan secara online serta respon mahasiwa melalui wawancara.

\section{HASIL PENELITIAN DAN PEMBAHASAN}

Model pembelajaran blended learning memerlukan media yang cocok dalam proses pembelajaran (Sandi, 2012). Media yang digunakan pada model blended learning ini adalah media elektronik (e-learning). Salah satu jenis penerapan dari pembelajaran elektronik (e-learning) adalah pembelajaran berbasis web dengan platform 
Schoology. Pemilihan schoology didasarkan kepada unsur penggunaan media dalam teknologi pendidikan dimana peserta didik dapat kapan saja dan dimana saja untuk mengakses selanjutnya hal yang terpenting adalah fiture-fiture yang dapat mengarahkan siswa untuk belajar mandiri serta mengembangkan kreativitas peserta didik. Dimana mereka memungkinkan berada di dunia yang berbeda, namun bisa saling memberi feedback, bertanya, menjawab, berinteraksi antara peserta didik dengan pendidik atau antara peserta didik dengan peserta didik.

Kata blended learning berasal dari bahasa Inggris, yang terdiri dari dua suku kata, blended dan learning. Blended berarti campuran atau kombinasi, sedangkan learning berarti pembelajaran. Jadi, blended learning bisa berarti pembelajaran campuran. Blended learning, menurut Smaldino (Smaldino, Lowther, \& Russel, 2008) ialah pembelajaran hybrid, yaitu mencampurkan dan pengaturan pembelajaran yang divariasikan agar sesuai dan tepat untuk memenuhi kebutuhan belajar peserta didik. Pencampuran tersebut dalam pembelajaran memang dibutuhkan untuk mencapai tujuan pembelajaran.

Sejalan dengan Smaldino, menurut Graham (Meikle \& Young, 2012) mendefinsikan bahwa blended learning adalah sebuah sistem yang mengkombinasikan pembelajaran tatap muka dan pembelajaran berbantuan komputer. Dengan mengintegrasikan penggunaan media berbasis komputer untuk membantu penyampaian materi ajar. Sedangkan
Watson merinci pengertian blended learning sebagai kegiatan pembelajaran yang mengkombinasikan komponen online learning dengan pendidikan tatap muka.

LMS berbasis Schoology menurut Tugiyo Aminoto dan Hairul Pathoni sebagaimana yang dikutip oleh Dian Ernida (Ernida, 2016) merupakan website yang memadu elearning dan jejaring sosial. Schoology sebagai sebuah LMS mempunyai banyak kelebihan. Membangun elearning dengan Schoology juga lebih menguntungkan bila dibandingkan karena tidak memerlukan hosting dan pengelolaan Schoology (lebih user friendly). Fitur-fitur yang dimiliki Schoology adalah sebagai berikut: Courses, Group, Discussion, Resources, Quiz, Attendance, dan Analytics.

Karakteristik blended e-learning adalah merupakan sumber suplemen dengan menggunakan pendekatan tradisional juga mendukung lingkungan belajar virtual melalui suatu lembaga dan rancangan pembelajaran yang mendalam pada saat perubahan tingkatan praktik pembelajaran dan pandangan tentang semua teknologi digunakan untuk mendukung pembelajaran (Kintu, Mugenyi Justice Zhu \& Kagambe, 2017). Penerapan suatu model pembelajaran harus berdasarkan teori belajar yang cocok untuk proses pembelajaran agar kelangsungan proses tersebut dapat sesuai dengan tujuan yang telah ditentukan (Rosenberg, 2011).

Pemilihan sychoology ini di latarbelakangi karena beberapa hal diantaranya mudah diakses oleh 
mahasiswa, fitur yang lengkap dapat membantu proses pembelajran dengan berbagai macam media, aktivitas kegiatan dapat dipanatu dengan adanya grup discussion, serta analisis dan presensi mahasiswa.

Beberapa menu yang dapat membantu proses pemeblajaran berlangsung adalah sebagai berikut; Menu-menu yang terdapat dalam aplikasi Schoology antara lain:

1)Courses, dengan menu courses, pengguna dapat membuat kelas baru, bergabung dengan kelas yang sebelumnya sudah ada atau browsing melalui daftar kelas yang telah ditetapkan.

2) Groups, berfungsi seperti pesan dinding di mana anggota grup juga dapat mem-posting pesan dinding. Ketika bergabung dengan sebuah grup, pengguna dapat mencari bagian dari grup yang pengguna inginkan.

3) Resources, untuk menjaga, melacak dokumen, file, dan gambar yang pengguna upload dalam kelas.

4) Recent Activity, untuk menampilkan berita terbaru yang terdapat pada akun Schoology. Kita dapat mem-posting dan meng-update dalam akun serta memilih halaman mana yang akan pengguna posting.

5) Calendar, untuk menampilkan halaman kalender yang telah di-posting sebelumnya di Recent Activity.

6) Messages, untuk mengirimkan pesan atau melihat pesan antara sesama pengguna Schoology.

7) People, untuk dapat melihat daftar pengguna dalam suatu kelas.

\section{Perencanaan Pembelajaran Blan- ded Berbasis Schoology pada Mata Kuliah PAI.}

Secara mendasar terdapat tiga tahapan dasar dalam model blended learning yang mengacu pembelajaran berbasis ICT, seperti yang diusulkan oleh Grant Ramsay yakni:

1) Seeking of information, Tahapan seeking of information, mencakup pencarian informasi dari berbagai sumber informasi yang tersedia di TIK, memilih secara kritis diantara sumber penyedia informasi dengan berpatokan pada content of relevantion, content of validity/ releability, dan academic clarity. Pengajar berperan sebagai pakar yang dapat memberikan masukan dan nasehat guna membatasi pembelajar dari tumpukan informasi potensial dalam TIK.

2) Acquisition of information, Pada tahapan acquisition of information, pelajar secara individual maupun dalam kelompok kooperatif kolaboratif berupaya untuk menemukan, memahami, serta mengkonfrontasikannya dengan ide atau gagasan yang telah ada dalam pikiran pelajar, kemudian menginterprestasikan informasi/pengetahuan dari berbagai sumber yang

3) Synthesizing of knowledge. Pada tahapan acquisition of information, pelajar secara individual maupun dalam kelompok kooperatif kolaboratif berupaya untuk menemukan, memahami, serta mengkonfrontasikannya dengan ide atau gagasan yang telah ada dalam pikiran pelajar, kemudian menginterprestasikaninformasi/pengetahuan dari berbagai sumber yang tersedia, sampai mereka mampu kembali mengkomunikasikan dan menginterpretasikan ide-ide dan hasil interprestasinya menggunakan fasilitas 
TIK. Tahap terakhir pembelajaran berbasis TIK adalah tahap synthesizing of knowledge adalah mengkonstruksi/merekonstruksi

pengetahuan melalui proses asimilasi dan akomodasi bertolak dari hasil analisis, diskusi dan perumusan kesimpulan dari informasi yang diperoleh.

Pembelajran blended leraning pada mata kuliah PAI telah diterapkan selama satu semester dengan komposisi $20 \quad \%$ dari jumlah pertemuan yang dilakukan. Yakni dengan 2 materi dengan 4 kegiatan belajar. Materi yang dipilihkan adalah "Bagaimana Manusia Bertuhan?" dan "Bagaimana Pribumisasi Islam".

Desain

perencanaan pembelajaran pada penelitian ini menggunakan model blended learning dengan pendekatan konstruktif. Adapun perencanaan pembelajaran mencakup analisis kebutuhan yang dilakuan dengan wawancara kepada mahasiswa yang belajar PAI pada awal pertemuan. Dari beberapa data diperoleh bahwa pembelajara PAI yang selama ini dilakuakan di Perguruan Tinggi masih di dominasi oleh pendekatan konvensional.

Ide utama objek pembelajaran (learning object) adalah untuk memecah materi ajar menjadi penggalan-penggalan materi kecil yang dapat digunakan dalam berbagai lingkungan belajar (Wiley, 2003). Dalam matakuliah PAI, pemebelajaran di lakukan melalui tiga kegiatan pembelajaran yaitu: mempelajari materi, memperdalam materi, dan mengukur penguasaan materi.
Materi pembelajaran yang diberikan pada mata kuliah PAI dengan menggunakan berbagai media seperti teks (.pdf, .doc), presentasi (.ppt, pez), video (.flv, .mov, .wmv). Untuk memperdalam materi, objek pembelajaran yang dibutuhkan adalah jenis objek pembelajaran yang dapat memfasilitasi interaksi antara peserta didik dengan instruktur/narasumber dalam hal ini secara maya (virtual). Yang termasuk objek pembelajaran jenis ini antara lain: laman web (.html), laman chating dan grup discussion. Untuk mengukur penguasaan materi, dapat menggunakan objek pembelajaran yang memiliki fitur latihan (self-test) seperti yang dapat dikerjakan kapan saja atau fitur tes sumatif (quiz) seperti terdapat di LMS Schoology yang hanya dapat dikerjakan pada waktu tertentu dengan lama waktu pengerjaan yang tertentu pula.

Pemetaan program adalah proses pemetaan komponenkomponen dalam bahan ajar berbasis web dan strategi/prosedur yang akan digunakan bersama bahan tersebut untuk mencapai kompetensi belajar yang diharapkan. Hasilnya adalah peta program yang menjelaskan serangkaian objek pembelajaran yang sudah tertata dan terorganisasi secara berurutan sesuai dengan urutan belajar yang dirancang serta strategi belajar/interaksi antar objek belajar tersebut, antar objek pembelajaran dengan peserta didik yang belajar, dan antara objek pembelajaran, mahasiswa, dan sumber belajar lainnya (Seamloc, 2008). 


\section{Implementasi Model Pembelajran berbasis Schoology pada Mata Kuliah PAI}

Implementasi penerapan model blended learning pada pembelajaran PAI dilakukan pada seluruh mahasiswa dengan langkah-langkah kegiatan pembelajaran yang telah didesain dalam tahap perencanaan model pembelajaran blended learning. Adapun langkah-langkah kegiatan pembelajaran dengan model blended learning, meliputi: kegiatan pendahuluan, inti, dan penutup yang didalamnya melibatkan langkah orientasi, organisasi, investigasi, presentasi, dan analisis serta evaluasi.

Kegiatan pembelajaran dilakukan sebagaimana dengan model blended leraning dengan karakteristik sebagai:

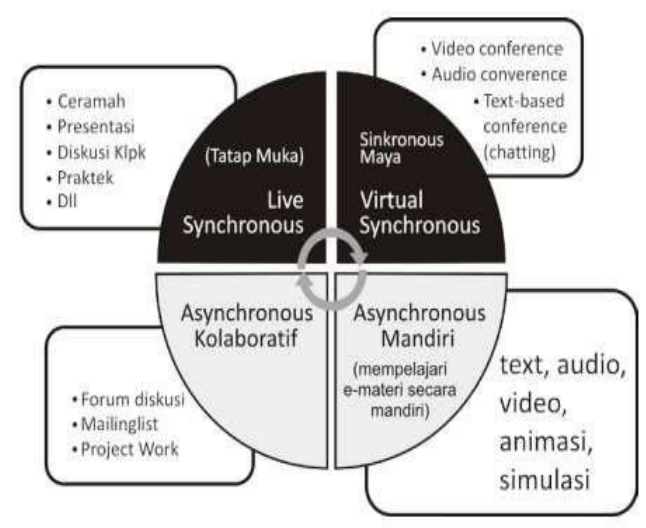

\section{Bagan 1. Karakteristik dan setting blended learning}

Proses belajar sinkron adalah proses di mana instruktur dan peserta didik mempelajari hal yang sama pada waktu yang bersamaan. Proses ini dibagi lagi menjadi tatap muka (live synchronous) di mana instruktur dan peserta didik berada pada tempat yang sama, dan sinkron maya (virtual synchronous) di mana instruktur dan peserta didik terpisah atau berada pada tempat yang berbeda. Pada proses belajar sinkron maya inilah e-learning berperan besar dalam menjembatani proses pembelajaran.(Ghazali, 2008)

Sedangkan proses belajar asinkron adalah proses di mana instruktur dan peserta didik benarbenar terpisah baik waktu maupun tempat. Sama seperti sinkron maya, elearning kembali menjadi sarana pembelajaran. Proses belajar asinkron dibagi menjadi asinkron mandiri dan asinkron kolaboratif. Pada asinkron mandiri peserta didik diarahakan untuk mempelajari bahan ajar elektronik (e-materi) secara mandiri dan kemudian mengerjakan tugas atau latihan secara mandiri pula. E-materi dapat berupa file teks, gambar, suara, video, atau animasi. Pada asinkron kolaboratif, instruktur mempersiapkan kegiatan belajar di mana peserta didik dapat mengerjakan secara berkelompok dan hasil belajar diukur melalui hasil kerja kelompok tersebut. Wadah yang dapat digunakan antara lain forum diskusi online, mailing list, atau pembelajaran berbasis proyek menggunakan social media (Ghazali, 2008). 


\begin{tabular}{|c|c|c|}
\hline No & Kuadran & Deskripsi \\
\hline 1. & $\begin{array}{l}\text { Kuadran } \\
1 \text { (live } \\
\text { synchrono } \\
\text { us) }\end{array}$ & $\begin{array}{l}\text { a. dilaksanakan } \\
\text { dalam } \\
\text { pembelajaran } \\
\text { tatap muka } \\
\text { dengan strategi } \\
\text { dan metode } \\
\text { pembelajaran; } \\
\text { b.strategi } \\
\text { pembelajaran } \\
\text { dalam iam } \\
\text { penelitian ini } \\
\text { adalah } \\
\text { pembelajaran } \\
\text { berbasis } \\
\text { masalah } \\
\text { (problembased } \\
\text { learning); } \\
\text { c. metode } \\
\text { pembelajaran, } \\
\text { meliputi: } \\
\text { ceramah, } \\
\text { praktik, } \\
\text { diskusi, } \\
\text { presentasi, } \\
\text { demonstrasi, } \\
\text { dan lain-lain: } \\
\text { ceramah yang } \\
\text { digunakan } \\
\text { adalah ceramah } \\
\text { konstruktif di } \\
\text { awal dariam } \\
\text { pembelajaran; } \\
\text { praktik dalam } \\
\text { blended learning } \\
\text { lebih diarahkan } \\
\text { pada kegiatan } \\
\text { pemecahan } \\
\text { masalah disking } \\
\text { pengetahuan; } \\
\text { disknsi ded learning } \\
\text { lebih diarahkan }\end{array}$ \\
\hline
\end{tabular}

\begin{tabular}{|c|c|c|}
\hline & & $\begin{array}{l}\text { pada kegiatan } \\
\text { menggali ide- } \\
\text { ide untuk } \\
\text { mengkonstruks } \\
\text { ikan } \\
\text { pengetahuan; } \\
\text { diskusi dalam } \\
\text { blended learning } \\
\text { lebih diarahkan } \\
\text { pada kegiatan } \\
\text { menggali ide- } \\
\text { ide untuk } \\
\text { mengkonstruks } \\
\text { ikan pengetahuan }\end{array}$ \\
\hline 2. & $\begin{array}{l}\text { Kuadran } \\
2 \text { (virtual } \\
\text { synchrono } \\
\text { us) }\end{array}$ & $\begin{array}{l}\text { a. pembelajaran } \\
\text { dilakukan } \\
\text { dalam waktu } \\
\text { yang } \\
\text { bersamaan } \\
\text { namun dalam } \\
\text { dimensi } \\
\text { ruang yang } \\
\text { sama/berbed } \\
\text { a, meliputi: } \\
\text { video } \\
\text { conference, } \\
\text { audio } \\
\text { converence, } \\
\text { chatting; } \\
\text { b. virtual } \\
\text { synchron } \\
\text { ous } \\
\text { merupak } \\
\text { an } \\
\text { perlua } \\
\text { san live } \\
\text { synchron } \\
\text { ous } \\
\text { dengan } \\
\text { memanfa } \\
\text { atkan } \\
\text { teknologi }\end{array}$ \\
\hline
\end{tabular}




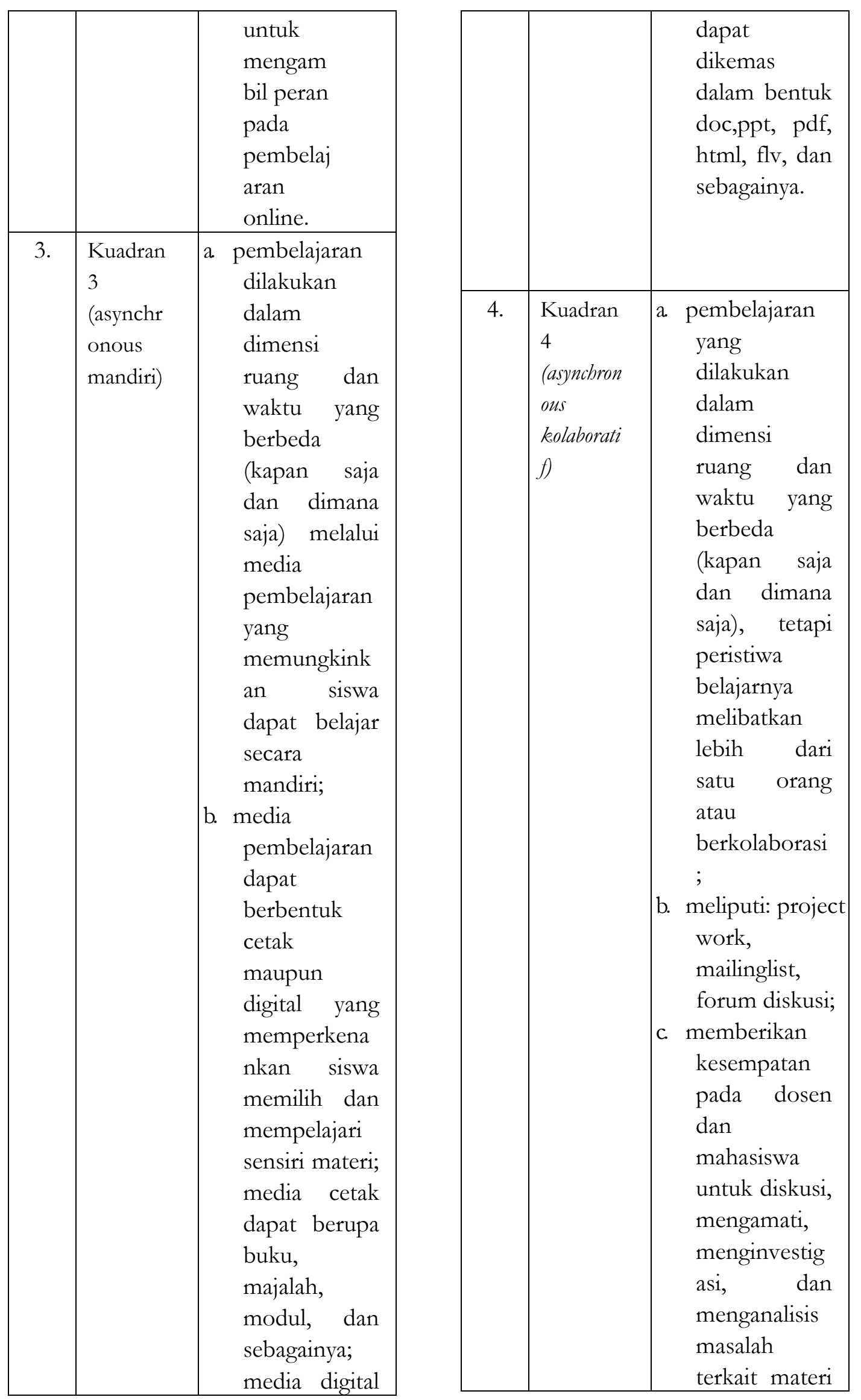




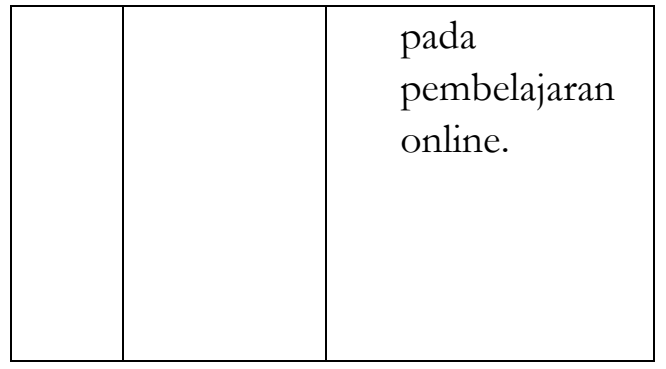

Tabel 1. Impelemtasi Pembelajaran Blended Learning

Secara garis besar pembelajarn dilakukan dengan 3 kegiatan yakni sapaan belajar atau kegiatan pembuka, intik kegiatan dan penutup yang beruapa evaluasi.

Kegiatan inti dimulai dengan langkah orientasi dimana kedua belah pihak memalukan Login di Sychoology untuk mengakses pembelajaran online dan mengenalkan materi. Selanjutnya, dosen menyapa mahasiswa dengan mengikuti sekaligus mengecek kehadiran mahasiswa dengan melakukan absesni online dengan menggunakan aplikasi zoho abesensi dilakukan selama 15 menit, setelah semuanya selesai masing-masing mahasiswa diberikan akses untuk dapat membaca materi dalam bentuk file pdf, PPT dan Video yang memuat berbagai macam hyperlink. Setelah masing-masing mahasiswa mendapatkan materi. Diminta untuk menganalisis sebuah Video serta memasukan analisis tersebut dalam kolom komentar. Dimana masingmasing mahasiswa diwajibkan untuk mengomentari hasil analisis teman yang lainnnya. Pada sessi ini terbuka untuk mereka dapat berdiskusi satu sama lain

\section{Respon Mahasiswa terhadap Pembelajaran Blended Learning pada Mata Kuliah PAI}

Pembelajaran blended learning dalam mata kuliah PAI dengan menggunakan Sychoology merupakan hal yang baru bagi mahasiswa. Oleh karenanya, responnya pun beragam. Pada pertemuan pertama dikontrak perkuliahan bahawa mata kuliah PAI $80 \%$ tatap muka dan 20\% memalui online. Yakni dengan 2 materi pembelajaran yang dilakuakan dengan menggunakan Sychoology dengan 2 kali kegiatan belajar.

Respon mahasiawa tidak diukur dalam bentuk angka melainkan dengan wawancara langsung secara terbuka. Dari 34 mahasiswa yang mengikuti perkulihan 30\% merasakan kesulitan dengan menggunakan Sychoology hal ini dikarenakan mereka baru mengenal dan belum terbiasa mengikuti perintah-perintah yang ada. Sementara yang lainnya dapat mengikuti perkulihan dengan blened learning berbasis Sycholoogy dengan baik.

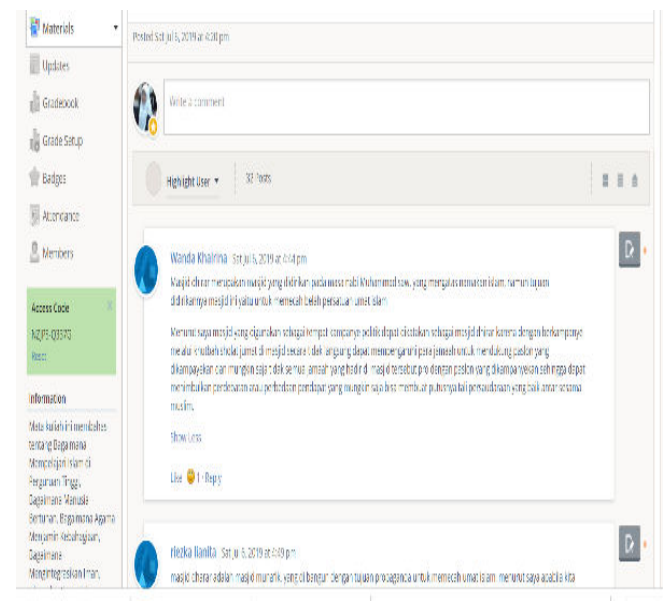




\section{Gambar 1. Respon Mahasiwa dalam Pembelajaran Berbasis Schoology}

Gambar di atas menunjukan bahwa mahasiswa aktif mengikuti perkuliahan dengan blended learning berbasis schoology hal ini dapat terlihat dari respon mahasiswa dalam menjawap pertanyaan dan berdisuksi, dari jumlah mahasiswa sebanyak 34 mahasiswa 32 mahasiswa yang telah memposting kegiatan pembelajaran. Di sisi lain, hal ini menunjukan bagaimana keaktifan mahasiwa dalam mengikuti pembelajaran dan antusias mereka dapat terlihat dari aktivitas serta komentar mereka saat perkuliahan berlangsung.

Secara keseluruhan mereka sepakat perlu adanya inovasi pembelajaran dengan memanfaatkan ICT. Sebagaimana yang telah dijelaskan di awal sebagai latar belakang penelitian bahwa mata kuliah PAI dipandang sebagai mata kuliah suplementer dan pemenuhan Sks sehingga pada proses pembelajarannya tak jarang mahasiswa yang antusias terhadap mater PAI. Selanjutnya metode pembelajaran PAI yang selama ini diajarkan di dunia Pendidikan lebih cenderung dengan metode ceramah yang membuat kejenuhan dalam belajar. Dari aspek materi yang diajarkan tidak jarang pembahasannya kurng difahami dalam kehidupan sehari-hari. Dengan pembelajaran online yang kaya akan konten maka mahasiswa dapat diarahkan untuk membaca berbagai macam litelatur sehingga memperkaya pengetahuan mengenai agama. Di sisi lain video dalam pembelajaran membukan pengetahuan baru kepada mahasiswa sehingga tidak bosan dengan hanya membaca.

Dapat disimpulkan bahawa secara keseluruhan bahwa mereka setuju dengan adanya pembelajaran berbasis blended learning sebagai bentuk inovasi terkait media pembelajaran yang digunakan dalam pembelajaran PAI serta mengenalkan mereka terhadap LSM baru yang selama ini merka kenal dengan Moodle dan Google Clasroom.

Interaksi yang terjadi dalam pembelajaran blended dapat menunjang perubahan kognitif yang terjadi pada mahasiswa. Hal ini ditunjukkan saat dilakukan diskusi online, antar mahasiswa satu dengan yang lain akan saling bertukar pikiran untuk menyelesaikan pertanyaan. Kegiatan diskusi tersebut, secara tidak langsung memfasilitasi mahasiswa untuk mengkonstruksi pengetahuannya sendiri.

Pertukaran pemikiran ini akan membentuk pemahaman tentang materi yang mereka bahas sehingga akan terjadi perubahan kognitif pada mahasiswa. Saat melakukan diskusi online, tampak beberapa mahasiswa memberikan jawaban atas soal yang diberikan pengajar dengan memberikan link alamat web lain yang mereka cari sendiri sebagai alternatif pengetahuan tambahan untuk menyelesaikan soal.

Hal ini berarti mereka juga mencari sumber pengetahuan tambahan lain sumber belajar yang diberikan pengajar. Berdasarkan hal tersebut, tampak bahwa konstruksi pemahaman mahasiswa atau perubahan kognitif yang terjadi saat 
pembelajaran model blended learning terjadi saat mahasiswa melakukan diskusi online

\section{KESIMPULAN}

Berdasarkan hasil penelitian dan pembahasan yang telah dilakukan, maka dapat ditarik kesimpulan sebagai berikut: 1) Perencanaan pembelajaran PAI dengan model blended learning menunjukkan tujuan yang hendak dicapai, materi pembelajaran, sesuai dengan konten pembelajaran PAI. Ditinjau dari komponen sistem pembelajaran menunjukkan tujuan, materi, metode, media, dan evaluasi model blended learning sesuai dengan pokok bahasan materi pembelajaran PAI. Dari kunci model blended learning menunjukkan adanya live event, selpaced learning, collaboration, assesment, and performance support learning yang sesuai dengan materi dan kegiatan pembelajaran PAI; 2) Model pembelajaran blended learning dapat diimplementasikan sesuai perencanaan pembelajaran yang mengkombinasikan pembelajaran synchronous dan asynchronous. Adapun implementasi model pembelajaran blended learning sesuai dengan proportion of content delivered online tipe kelas blended/bybrid dengan adanya kombinasi pembelajaran tatap muka dan online. Implementasi model pembelajaran blended learning pada kegiatan pembelajaran dilakukan dengan sebagai kegiatan inti di mana konsepnya mahasiswa learning by self. Peran dosen sebagai fasilitator; dan 3) Pembelajaran dengan model blended learning secara keseluruhan mendapat respon positif di mana mahasiswa dapat mengakses berbagai materi secara online sesuai dengan instruksi yang telah tersedia. Mahasiswa dapat belajar secara mandiri dan berkolaborasi. Respon umum mahasiswa secara mayoritas perlu adanya model pembelajaran PAI yang inovatif.

\section{REFERENSI}

Ernida, D. (2016). Pengembangan ELearning Dengan Schoology Sebagai Suplemen Pembelajaran Fisika Pada Materi Kinematika Gerak (Universitas Bandar Lampung). Retrieved from http://digilib.unila.ac.id/23484/ 19/SKRIPSI TANPA BAB PEMBAHASAN.pdf

Ismarjiati, M. T. N., Rusdin, M. E., Herawati, R., Nurulia, E., Sulisworo, D., \& Suritno, F. (2019). Implementation of Elearning Using Schoology to Improving the Interest Learning Physics at DeBritto High School. International Journal of Research and Innovation in Social Science (IJRISS), 3(6), 185. Retrieved from https://www.rsisinternational.or $\mathrm{g} /$ journals/ijriss/Digital-

Library/volume-3-issue-6/185189.pdf

Kintu, Mugenyi Justice Zhu, C., \& Kagambe, E. (2017). Blended learning effectiveness: the relationship between student characteristics, design features and outcomes. International Journal of Educational Technology in Higher Education, 14(1), 5. https://doi.org/DOI 
10.1186/s41239-017-0043-4

Meikle, G., \& Young, S. (2012). Media Convergence: Networked Digital Media in Everyday Life. Basingstoke: Palgrave Macmillan. Rosenberg, M. J. (2011). E-Learning: Strategies For Delivering Knowledge In The Digital Age. USA: McGraw-Hill Companies.

Sandi. (2012). Pengaruh Blended Learning Terhadap Hasil Belajar Kimia Ditinjau Dari Kemandirian Siswa. Jurnal Pendidikan \& Pengajaran, 241.

Setiyani, S. (2019). Blended Learning: The Effectiveness Of Schoology Based E-Learning On Mathematic Communication Ability. Jurnal Kependidikan, 3(2), 145.

https://doi.org/https://doi.org /10.21831/jk.v3i2.23820

Smaldino, S. E., Lowther, D. L., \& Russel, J. D. (2008). Instructional Technology and Media for Learning (Ninth Edition). Pearson Education Inc.

Suana, W., Maharta, N., Nyeneng, I. D. P., \& Wahyuni, S. (2017). Design And Implementation Of Schoology-Based Blended Learning Media For Basic Physics I Course. Jurnal Pendidikan IPA Indonesia, 6(1), 170. https://doi.org/DOI: 10.15294/jpii.v6i1.7205

Undang-Undang Republik Indonesia Nomor 20 Tahun 2003 Tentang Sistem Pendidikan Nasional. (n.d.). Retrieved from https://sipuu.setkab.go.id/PUU doc/7308/UU0202003.htm

Zaki, M. (n.d.). PENDIDIKAN AGAMA ISLAM DI
PERGURUAN

TINGGI

UMUM

BERBASIS

MULTIKULTURALISME. 